\title{
Hemsömmerskornas yrkesliv
}

Malin Nilsson

Historisk forskning om social mobilitet och arbetskraftsrörlighet handlar oftast om män. I många fall utgår forskare från att det helt enkelt inte går att studera kvinnor eftersom de ofta uppträder utan yrkestitlar i källorna. Det gör att vi vet mindre om kvinnors förvärvsarbete, och levnadsbanor, än om mäns, och allra minst vet vi om gifta kvinnors förvärvsarbete. Ett alternativ till att exkludera kvinnor helt är att försöka pussla ihop information om deras arbetsliv från olika sorters källor. Det tar oftast längre tid och är därför bara möjligt att göra för avgränsade grupper. Fördelen är dock att vi kan få en mer nyanserad bild än om vi endast använder en sorts källa.

\section{Frågeställningar}

I det här kapitlet studerar jag kvinnors mobilitet i Göteborg i början av 1900-talet genom att fokusera på gruppen hemsömmerskor. En av anledningarna till mitt val av just hemsömmerskor är att andelen gifta kvinnor var större i denna grupp än i andra grupper på arbetsmarknaden. Genom att kombinera mantalslängder med ett rikt intervjumaterial som samlades in av en samtida utredning försöker jag såväl fördjupa vår kunskap om kvinnors levnadsbanor under 1900-talets första hälft som få en bild av vad det är vi missar om vi bara använder standardkällor. För att göra det ställs två frågor till materialet: 
1 Var äktenskap för kvinnor förknippat med ett steg "nedåt", till mindre kvalificerade uppgifter?

2 Finns det en diskrepans mellan gifta kvinnors faktiska deltagande i arbetskraften och den som syns i befolkningsregister, såsom mantalslängder?

\section{Kvinnors arbete i källorna}

Generellt är det svårare att hitta kvinnors arbete i historiska källor än mäns, ${ }^{1}$ och gifta kvinnors arbete är särskilt svårt att hitta. Det kan ha ideologiska orsaker - att kvinnorna beskrivs eller beskriver sig själva som icke-förvärvsarbetande för att passa in i en manlig försörjarnorm - men det kan också bero på tekniska riktlinjer för hur statistiken samlades in, till exempel att gifta kvinnor av rutin skrev som "hustru" även om de hade ett yrke. Vi kan se detta mönster tydligt i den här boken, bristen på gifta kvinnor med yrkestitlar i mantalslängderna är påtaglig. Mantalslängderna är en relativt tillförlitlig källa för att följa mäns arbete, och den fungerar oftast bra för ogifta kvinnors arbete. Men få gifta kvinnor registrerades någonsin med yrke i mantalslängderna under första delen av 1900-talet. ${ }^{2}$ Många kvinnor lämnade arbetskraften när de gifte sig, ${ }^{3}$ men med tanke på att reallönerna var låga har vi anledning att tro att vissa gifta kvinnor faktiskt fortsatte att förvärvsarbeta. Det kunde behövas flera inkomster för att försörja en arbetarklassfamilj. ${ }^{4}$ Tidigare forskning har visat att det var vanligt att gifta arbetarklasskvinnor arbetade deltid som hjälphustrur, tvätterskor eller hemsömmerskor. ${ }^{5}$ Detta arbete syns inte i mantalslängden eftersom kvinnorna sannolikt inte arbetade heltid eller kom upp i en taxeringsbar inkomst (se kapitel 2 och 3).

När allas arbete inte speglas i historiska källor får vi en snedvriden bild av hur arbetskraften faktiskt såg ut i början av 1900-talet. Vi behöver då leta efter alternativa källor för att komplettera bilden. Ofta behövs flera källor, vad historikern Lotta Vikström (2011) kallat triangulering, för att kunna få en korrekt bild. I vår studie kompletteras mantalslängderna av 336 intervjuer som gjordes med hemsömmerskor i Göteborg 1912. De var en del i en stor nationell 
hemindustriutredning med syfte att kartlägga hemindustrins ekonomiska och sociala natur. ${ }^{6}$ Intervjuerna innehåller omfattande information om hemindustriarbeterskornas utbildning och tidigare yrkeserfarenhet och hur länge de arbetat i hemindustrin. Där finns också information om produkter, löner och arbetsförhållanden samt familjestruktur, inkomst och boende.

Totalt gjordes inom utredningen 4257 intervjuer med kvinnliga hemindustriarbetare i Sverige, varav en stor del i Västra Sverige, i Göteborg och Sjuhäradsområdet söder om Borås. Här fanns också majoriteten av de totalt cirka 30 ooo hemindustriarbetare i Sverige som identifierades i samband med utredningen. Det verkliga antalet var dock sannolikt större.

\section{Kön, civilstånd och mobilitet}

Utifrån vad vi vet om historiska arbetsmarknader finns all anledning att tro att kvinnor rörde sig inom, in på och ut från arbetsmarknaden på ett annorlunda sätt än män gjorde. ${ }^{7}$ Trots detta finns det relativt få studier som följer kvinnors rörlighet på arbetsmarknaden över tid. ${ }^{8}$

Lite hårdraget kan man säga att det till och med verkar som om anledningen till att kvinnor lämnas utanför forskningen skulle vara att de är för mobila. Kvinnor byter namn när de gifter sig, de rör sig in på och ut från arbetsmarknaden mer än män, de rör sig mellan formella och informella arbetsanställningar, de rör sig mellan betalt och obetalt arbete. En av de få större studier som finns om kvinnors arbetskraftsmobilitet i Sverige under tidigt 1900-tal bekräftar den här bilden: kvinnor rörde sig mer än män och allra mest rörde sig äldre gifta kvinnor. ${ }^{9}$

Civilstånd har länge varit en viktig faktor för mobiliteten på arbetsmarknaden, för både män och kvinnor. I det förindustriella samhället fanns ett system med "livscykeltjänst": unga män och kvinnor lämnade föräldrahemmet för att arbeta som drängar respektive pigor i jordbrukarhushåll. Sedan kunde de få disponera eller förvärva lite mark och ha en egen liten gård tillsammans med en partner. ${ }^{10}$ Man kan säga att Sverige hade en tydlig tvåförsörjarmodell och att 
ingå äktenskap var ett karriärsteg; både kvinnor och män hade arbetsuppgifter som var kopplade till högre status och makt efter att de var gifta. ${ }^{11}$

Såväl jordbrukarhushåll som hantverkarfamiljer var uppbyggda kring ett gift par som ledde. Att vara gift innebar oftast ett steg till relativ frihet för både män och kvinnor. Samtida debattörer kunde tala om tiden före äktenskapet som träldom och konstatera att man som gift i alla fall var fri. ${ }^{12}$

Med snabb befolkningstillväxt och ökad produktivitet i jordbruket under 180o-talet växte dock snabbt andelen tjänstefolk som förblev i anställning på någon annans gård även efter att de gift sig. Äktenskapet förlorade i kraft som en språngbräda för höjd yrkesstatus. För kvinnor fanns ibland alternativet att gifta sig med någon med egen gård och därmed få ökad social status, men även för kvinnor minskade sannolikheten att de skulle kunna driva ett självförsörjande hushåll. ${ }^{13}$

Samtidigt omformades den svenska arbetsmarknaden snabbt under 180o-talet, och det blev möjligt att söka sig till andra anställningar i den industrialiserade ekonomin. För män blev äktenskapet i allt mindre grad ett steg mot mer kvalificerade arbetsuppgifter. Män började jobba på fabrik, i skogen, eller i hamnen som ogifta, och fortsatte arbeta där efter att de gift sig. För kvinnor, däremot, blev äktenskapet under industrialiseringen en ännu viktigare faktor. Men istället för ett steg mot mer kvalificerade arbetsuppgifter innebar det ofta en port ut från arbetsmarknaden till obetalt arbete i hemmet eller till mer tillfälliga anställningar.

I många ekonomier som går igenom en industrialiseringsprocess och ekonomisk tillväxt sjunker gifta kvinnors förvärvsfrekvens initialt för att senare stiga igen. Utvecklingen av gifta kvinnors arbetsmarknadsdeltagande under industrialiseringen ser ut som ett U. ${ }^{14}$ Hur djupt U-kurvan når är dock omdiskuterat. ${ }^{15}$

Många studier av den svenska arbetsmarknaden bygger på statistik sammanställd av statistikern Per Silenstam som källa för utvecklingen från $1870 .{ }^{16}$ För gifta kvinnor finns dock bara siffror på förvärvsfrekvens från 1920. Nationalekonomen Anita Nyberg har också kritiserat Silenstams data eftersom han inte inkluderat jordbrukarhustrur som 
Diagram 8.1. Gifta kvinnors förvärvsfrekvens inklusive och exklusive jordbrukarhustrur, Sverige 1880-1960 (procent). Källa: Silenstams siffror är tagna från Silenstam 1970, tabell A:15, s 105. Siffrorna för gifta kvinnors förvärvsintensitet om jordbrukarhustrur räknas som förvärvsarbetande kommer från Nyberg 1987, bilaga 1.

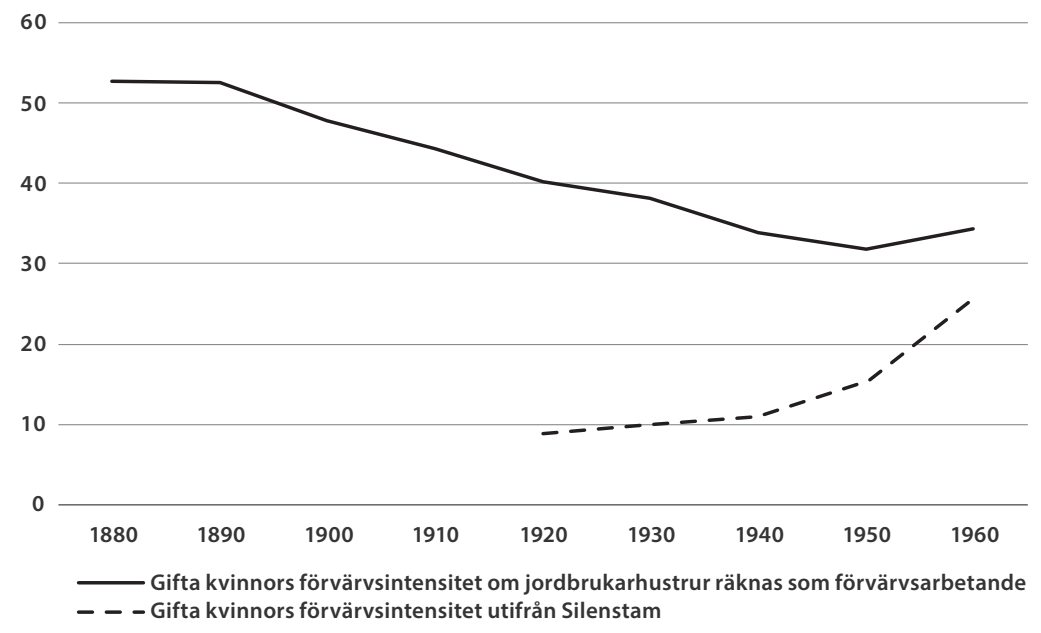

förvärvsarbetande. ${ }^{17}$ Som vi ser i diagram 8.1 förändrar det helt kurvan för gifta kvinnors förvärvsfrekvens i Sverige under 1900-talets första decennier.

Skulle de här siffrorna förändras ytterligare med en bättre bild av gifta kvinnors faktiska förvärvsarbete? Jag kommer i detta kapitel inte att kunna presentera nya siffror på samma sätt som Nyberg med jordbrukarhustrurna, men vi kan få en indikation på om det faktiskt är så att mycket av gifta kvinnors arbete döljs i den vanliga arbetsmarknadsstatistiken.

\section{Hemindustri, civilstånd och mobilitet}

Hemindustriarbete är industriell produktion som utförs i arbetarens hem på uppdrag av en arbetsgivare. Det har varit en central del av de flesta industrialiseringsprocesser och är fortfarande en viktig del av globala produktionskedjor. Både historiskt och i nutid produceras framförallt relativt billiga konsumtionsvaror i hemindustrin. Det 
kan vara saker som paraplyer, leksaker eller kläder. Hemindustriell tillverkning är ibland förknippad med protoindustriell tillverkning, alltså industriell produktion inom ramen för jordbrukssamhället. Det var vanligt till exempel i Sjuhäradsbygden under 1700- och 180o-talen. Men hemindustrin är industriell produktion inom ramen för industrisamhället.

Hemindustrin fanns på 1910-talet i hela landet men var framförallt koncentrerad till de stora städerna och Sjuhäradsområdet. Hemindustrin dominerades av beklädnadsindustrin, både i Göteborg och i övriga landet. I Göteborg var Wettergrens beklädnadsfabrik vid Stigbergsliden en stor arbetsgivare för hemindustriarbeterskor, närmare bestämt hemsömmerskor. År 1913 var Wettergrens det tredje största industriföretaget i Göteborg. De hade 1143 anställda varav ungefär hälften (593) var hemarbetare. ${ }^{18}$ Sannolikt var hemarbetarna ännu fler eftersom mycket av arbetet var utlagt på sömmerskor som hade egna verkstäder och i sin tur anställde kvinnor. Nyberg och Klintberg menar i sitt kapitel om Wettergrens i boken Små industrier (2019) att sömnaden fördes över till fabriken i högre grad under mellankrigstiden. ${ }^{19}$ De presenterar dock inga siffror på detta.

Kvinnors arbete i den svenska hemindustrin är ett relativt outforskat ämne. Förutom några tidiga utredningar som gjordes kring sekelskiftet har forskningen inte ägnat mycket uppmärksamhet åt hemindustrin i det industrialiserade samhället. ${ }^{20}$ Oftast nämns det i förbigående i översiktsverk om kvinnors arbete under 1900-talet eller i texter där forskningsfokus ligger någon annanstans. I dessa fall framställs kvinnors arbete i hemindustrin i början av 1900-talet nästan alltid som en möjlighet för gifta kvinnor att förvärvsarbeta. ${ }^{21}$ Det beskrivs som ett arbete som fungerade under den manliga försörjarnorm som rådde under större delen av 1900-talet i Sverige, en norm som föreskrev att mannen skulle förvärvsarbeta utanför hemmet och att kvinnan, som en förutsättning för detta, skulle utföra obetalt omsorgsarbete i hemmet. ${ }^{22}$ Med den manliga försörjarnormens expansion blev det dock svårare framförallt för gifta kvinnor att kombinera omsorgsarbete med betalt arbete. ${ }^{23}$ Arbetsgivarna föredrog manlig arbetskraft eller unga ogifta kvinnor utan 
direkt omsorgsansvar, och gifta kvinnor trängdes till viss del ut från arbetsmarknaden. ${ }^{24}$ Särlagstiftning för kvinnor, som nattarbetsförbud och en egen tillsynsmyndighet, snarare pressade ut kvinnor från den formella arbetsmarknaden än gynnade dem på densamma. ${ }^{25}$

Hemindustriarbetarna har ofta setts som ett extremt flexibelt arbetsmarknadssegment. I marxistisk tradition pratar man om dem som en reservarmé som används för att hantera efterfrågetoppar i produktionen. I arbetsmarknadsstudier pratar man ibland om hemindustrin som ett yrke med låga trösklar ut och in. Men det är också ett yrke som kan ses som ett dead-end job, ett lågkvalificerat yrke där kvinnor "blir kvar". ${ }^{26}$ Dock finns det extremt få longitudinella studier som följer hemarbetare över tid. Och det är där min studie kommer in. Först ska jag dock med ett enskilt livsöde visa hur vägen in i hemindustrin kunde se ut.

\section{Från ett båtsmanstorp i Halland till hemsömnad i Göteborg - en levnadsbana}

Anna Josefina Andersson föddes den 1 december 1875 i ett båtsmanstorp längst ute vid havet i en liten församling i mellersta Halland. Hon var tredje barnet i en barnaskara av sju. Under hennes första år bodde även hennes morfar med familjen, han står som backstugusittare och före detta båtsman i folkräkningen 1880 . Hennes pappa står som arbetskarl 1880, 1890 och som grovarbetare 1900, modern står endast som hustru.

Alma lämnade sitt föräldrahem i slutet av maj 1891, 15 år gammal. Samma år flyttade 80 personer från församlingen, nästan var tjugonde person. Många utvandrade till Amerika, men Alma flyttade till Göteborg. Hon kom till en ung familj i Annedal; hennes nya husmor var bara fem år äldre än hon själv och mannen i familjen var skräddare. Paret hade ett barn på tio månader. Kanske var det tänkt att Anna skulle passa flickan så hustrun kunde arbeta med sömnaden tillsammans med sin man. Men flickan blev sjuk och avled knappt två veckor efter att Anna flyttat dit. 
Det unga paret flyttade till Masthugget i november samma år och Alma flyttade vidare för att bli piga hos en änkefru med en stor våning nära domkyrkan. Åren efter arbetade Anna som piga i olika hushåll, men 1895 flyttade även hon till Masthugget och började där som elev på Wettergrens konfektionsfabrik.

Fem år senare, när Anna var 25 år, gifte hon sig och fick sitt första barn. Året innan hade hon köpt en symaskin för 135 kronor, sannolikt på avbetalning, och börjat arbeta som utesömmerska, det vill säga att hon sydde kappor i sitt eget hem istället för på fabriken.

När Socialstyrelsens hemindustrikommitté intervjuade Anna om hennes hemarbete 1912 hade hon hunnit få ytterligare två barn. Hon bodde med dem och sin man på Karl Johansgatan, i en lägenhet med två rum och kök. Mannen uppgavs arbeta som tunnbindare men Anna verkar inte ha velat eller kunnat ange om han hade bidragit med något till hushållets inkomst under det föregående året. Hon själv däremot arbetade tio timmar per dag och tjänade ungefär 25 kronor i veckan på sömnaden. Dock behövde hon betala en annan kvinna för att göra handsömnad och dessutom måste hon bekosta både tråd och silke själv, så veckoinkomsten landade under bra veckor på cirka 20 kronor.

Anna var medlem i Wettergrens sjuk- och begravningskassa. När hon fick frågan om hon haft några tidigare yrken svarade hon nekande, trots att det i församlingsarkiven ser ut som att hon arbetat som piga i flera hushåll. Kanske för att till skillnad från det yrke hon utövade nu, som sömmerska, såg hon "husligt arbete" som bara ett jobb.

När jag försökte följa Annas arbetsliv vidare i mantalslängderna fann jag att hon var en av få gifta kvinnor i mitt intervjumaterial som någon gång registrerades med ett yrke och en arbetsgivare. År 1928 stod hon som "sömmerska, hustru" och arbetade fortfarande för Wettergrens. Då var hon 53 år och har kanske jobbat kontinuerligt hos samma arbetsgivare i nästan 30 år. Men både före och efter stod hon endast som "hustru", så många av de frågor som kan ställas om hennes arbetsliv förblir obesvarade. Det går inte att få reda på om hon hade arbetat med något annat under tiden, om hon hade lämnat arbetsmarknaden under perioder eller om hon återvände till att arbeta inne på fabriken när barnen blivit större. 


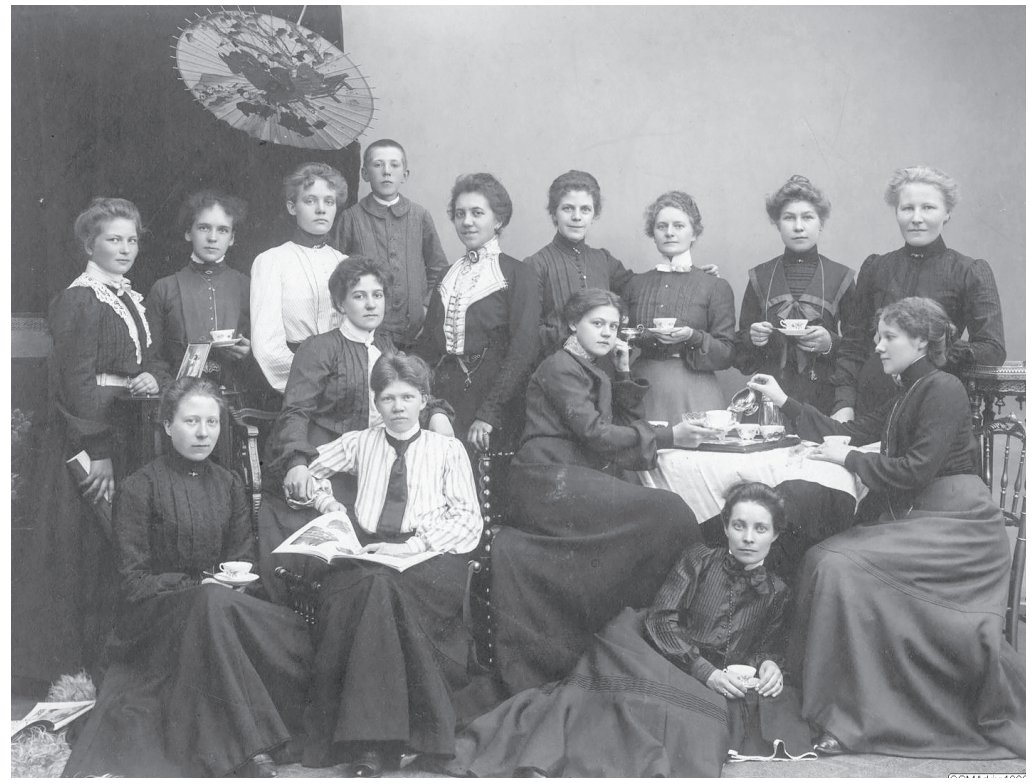

Bild 8.1. Personal i Hilda Perssons syatelié, Inom Vallgraven, på Östra Hamngatan 52 år 1902. Foto: William Steen Möller, Göteborgs stadsmuseum.

\section{Göteborgs hemsömmerskors mobilitet}

Anna Josefina tillhör en kohort bestående av 127 kvinnor som arbetade som hemsömmerskor i Göteborg 1912 och som jag följt framåt i tiden. Hemindustriarbetare i början av 1900-talet producerade, precis som hemindustriarbetare idag, olika saker. Det kunde vara tändsticksaskar, säckar eller snickerier. Men allra vanligast var det att vara sömmerska, eller mer specifikt det som kallades hemsömmerska.

För att besvara min första fråga, om det fanns ett samband mellan äktenskap och ett steg "nedåt" till mindre kvalificerat arbete, har jag studerat intervjuer som gjordes med hemsömmerskor i Göteborg 1912. Intervjuerna innehåller frågor om vad intervjupersonerna gjort innan de började arbeta inom hemindustrin (A i figur 8.1). För att besvara min andra fråga, om det finns en diskrepans mellan gifta kvinnors faktiska deltagande i arbetskraften och det som framträder i mantalslängder, har jag jämfört informationen i intervjuerna för 
B

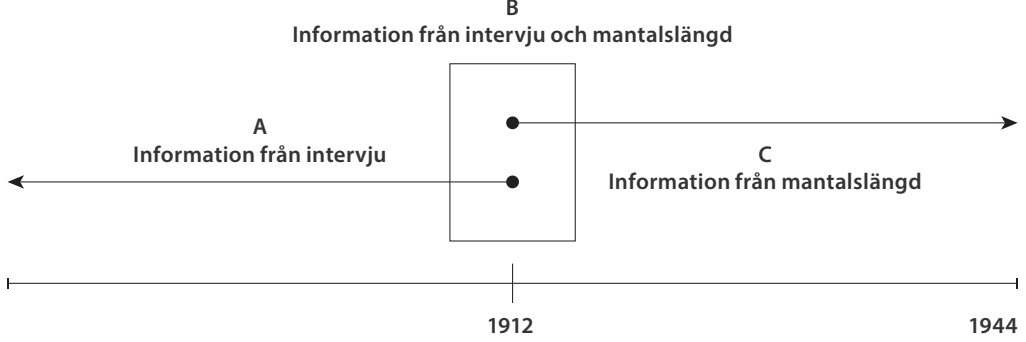

Figur 8.1. Källöversikt.

1912 med information ur 1912 års mantalslängd (B i figur 8.1). Jag har också följt samtliga kvinnor i 1912 års mantalslängd fram till 1944 för att se vad som går att säga om deras arbetsliv och om det skiljer sig åt mellan gifta och ogifta kvinnor (C i figur 8.1).

Totalt intervjuades 366 hemindustriarbetare i Göteborg 1912, 30 män och 336 kvinnor.

Av männen arbetade de flesta med sömnad, några få med skomakeri och snickerier. Bland kvinnorna tillverkade fyra skor, resten var hemsömmerskor. Intervjuerna finns transkriberade på ark av tunn kartong i Socialstyrelsens arkiv på Riksarkivet i Arninge utanför Stockholm. Det finns ett dubbelsidigt ark för varje individ. De är sorterade utifrån geografisk plats, men vissa intervjuer har hamnat fel så de var inte helt lätta att hitta. Totalt kunde jag få fram intervjuer med 276 kvinnliga respondenter från Göteborg, samtliga hemsömmerskor.

Mantalslängder är en återkommande källa i den här antologin. De var offentliga skatte- och befolkningsunderlag som samlades in varje år i Sverige. ${ }^{27}$ För varje hushåll innehåller de till exempel information om individers ålder, civilstatus, eventuella yrke, lön, arbetsgivare och om de hade några anställda. För att i mantalslängden kunna lokalisera de personer som fanns i intervjumaterialet använde jag Göteborgs stads centralregister. ${ }^{28}$

Men många av hemsömmerskorna hade vanliga namn och för att undvika att ta fel på person i mantalslängden använde jag Sveriges dödbok för att få tag på deras födelsedatum (födelseåret fanns i intervjuerna) och ibland även deras flicknamn alternativt namn som 


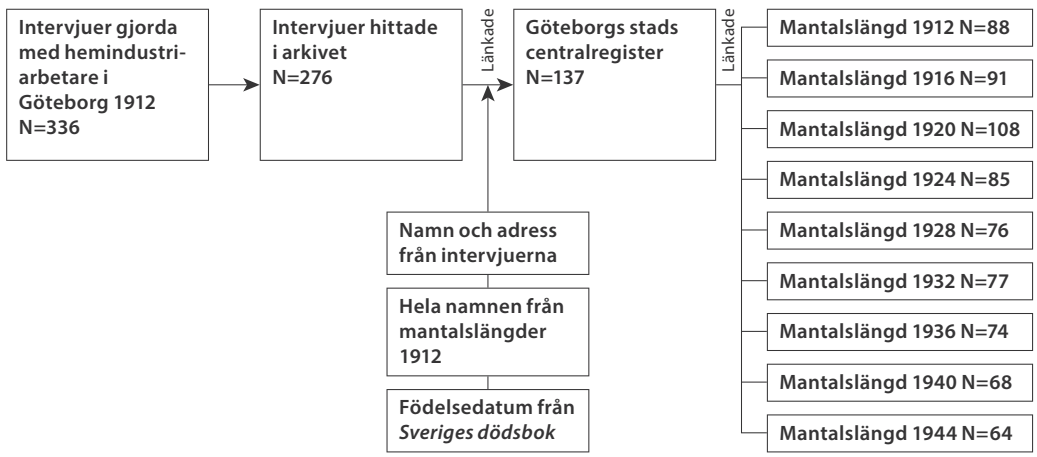

Figur 8.2. Länkningsprocess för att hitta hemsömmerskorna.

gifta. I intervjuerna ställdes en fråga om bostadsadress, så jag kunde gå till mantalslängden från 1912 och leta efter personen på den adress hon uppgett i intervjun. Där kunde jag samla in information om mellannamn och eventuella stavningar som avvek från intervjun. Med denna information började jag leta efter personerna i centralregistret.

Totalt hittade jag i centralregistret 137 av de 276 av kvinnorna jag letade efter. Med informationen om deras adress från centralregistret försökte jag hitta kvinnorna i mantalslängderna för 1912, 1916, 1920, 1924, 1928, 1932, 1936, 1940 och 1944. Hela länkningsprocessen beskrivs i figur 8.2.

Anledningen till att jag hittade så pass få kan vara att centralregistret inte blev riktigt fullständigt förrän 1920; innan dess var informationen retroaktiv. Kvinnorna kan ha flyttat från Göteborg mellan 1912 och 1920, vissa kan ha bytt namn om de gift sig och deras namn som ogifta fanns inte med i dödboken. En annan anledning kan vara att jag inte kunde vara riktigt säker på att jag hade hittat rätt person, till exempel saknades ibland information för att skilja mellan kvinnor med samma namn.

För att ta reda på hur bortfallet kunde påverka resultatet analyserade jag vilka det var som försvann. Den enda tendensen var att kvinnor som tjänade över 1000 kronor om året i hemindustrin hittades mer sällan. Det berodde troligtvis på att de oftast hade en egen syateljé och angav adressen till den i intervjun, istället för sin hemadress. 


\section{Vad betydde äktenskap för hemsömmerskornas mobilitet?}

Den typiska hemsömmerskan i Göteborg 1912 var ogift och mellan 30 och 39 år. Relativt få av dem levde dock själva, utan de bodde tillsammans med åldrade föräldrar, ogifta syskon eller vänner. Majoriteten av dem var födda utanför Göteborg och hade migrerat till staden, oftast från närliggande områden i norra Bohuslän och dåvarande Älvsborgs län. Ett exempel är Elin Olsson, som ursprungligen kom från Ödsmål norr om Stenungssund. När hon intervjuades var hon 31 år och bodde tillsammans med två äldre systrar på Vegagatan $i$ Linnéstaden. Alla tre systrarna var ogifta, och tillsammans hyrde de en liten syverkstad där de sydde kappor för Konfektionsbolaget Lesslie.

Ungefär 40 procent av hemarbetarna i materialet var gifta och av dem hade en majoritet hemmavarande barn. Bland de gifta kvinnorna var åldersfördelningen mer spridd än bland de ogifta. Det fanns endast ett fåtal ensamstående mödrar i gruppen. De gifta fällde dock relativt ofta kommentarer om att deras män av någon anledning inte kunde försörja familjen, ibland på grund av sjukdom eller arbetslöshet, ibland för att han drack eller inte längre bodde med familjen. I Karolina Börjessons fall står det att hon var gift och att hennes man var eldare på en båt, men inom parentes står det "övergiven". Karolina försörjde sin tvååriga dotter och treåriga son själv genom "div. konfektionssömnad".

Ännu oftare saknas det uppgifter om hur mycket mannen tjänat i intervjuerna. Det kan bero på att kvinnorna inte vill uppge mannens inkomst till exempel av rädsla för att beskattas annorlunda. Men det kan också ha varit så att mannen inte bidrog till hushållets försörjning.

De flesta hemsömmerskor sade sig vara linnesömmerskor, det vill säga att de sydde underkläder: daglinnen, underkjolar, underbyxor. Bland ogifta kvinnor var det vanligare att vara kappsömmerska. I en annan stad hade jag antagligen inte hittat så många kappsömmerskor, men i Göteborg låg konfektionsfabriken Wettergrens, som vid tillfället var en av Nordens största konfektionsfabriker. De anställde ett stort antal sömmerskor, både på fabriken och som hemsömmerskor. 
Tabell 8.1. Hemsömmerskornas åldersstruktur, hushållstyp och tidigare migration, Göteborg 1912. Anm: "Bor med släkting" = bor med någon som inte är förälder, syskon, barn eller make. Källa: Socialstyrelsens arkiv, 4:e byrån. Svensk hemindustri.

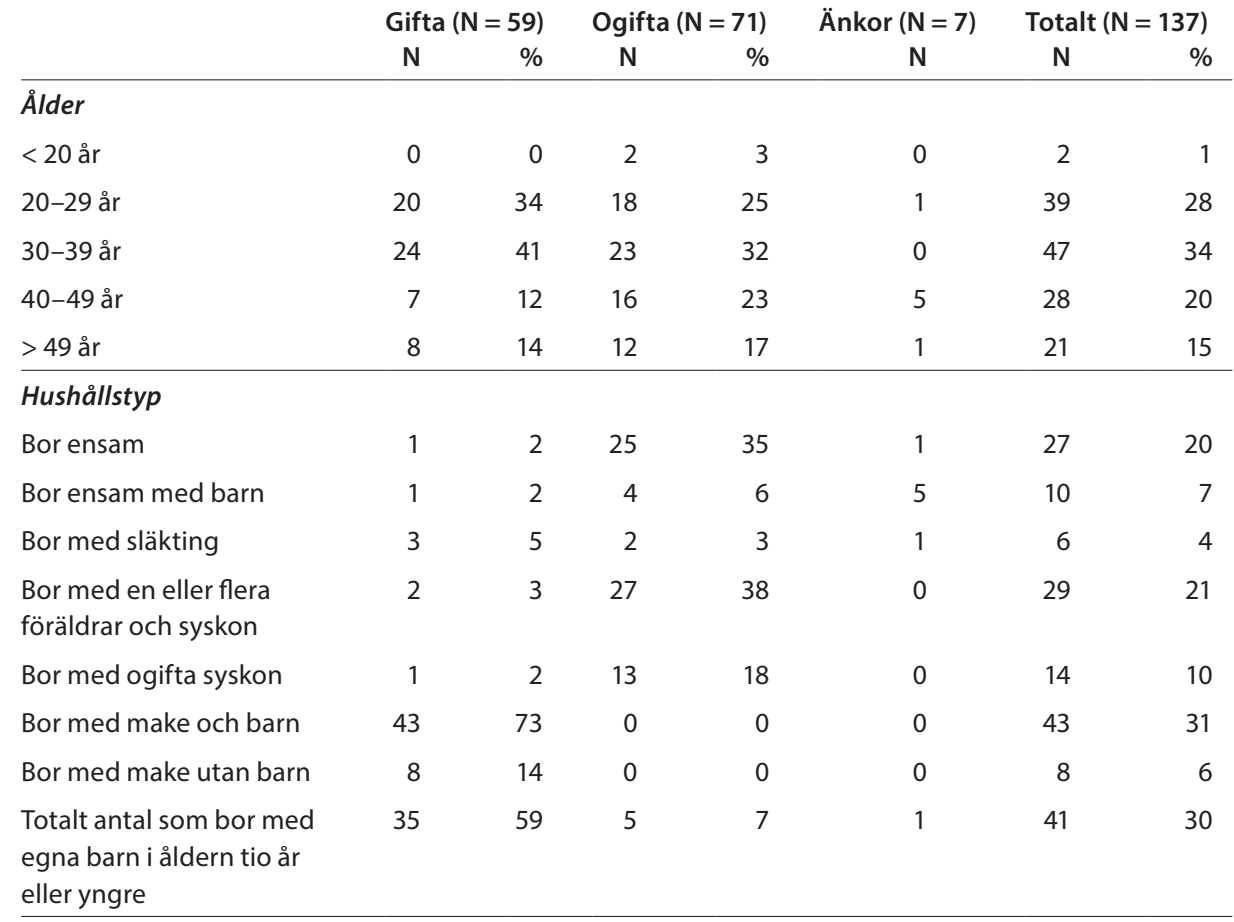

\section{Migration}

Ej född i Göteborg

42

$71 \quad 38$

54

6

86

63

Kappsömmerskorna hade oftare anställda jämfört med linnesömmerskor och brodöser. De hyrde också oftare en egen ateljé, som nästan alltid låg nära eller i anslutning till deras hem. Som vi kan se i tabell 8.2 var det dock inte särskilt vanligt att ha en egen verkstad, endast 12 procent av hemsömmerskorna hade det. I princip alla som hade en egen verkstad sydde kappor och arbetade för Wettergrens.

Änkor och ogifta kvinnor hade generellt arbetat längre i hemindustrin än gifta kvinnor, som framgår av tabell 8.3. Delvis har det att göra med åldersstrukturen i grupperna, men även om man tar hänsyn till ålder hade de ogifta i snitt arbetat längre i hemindustrin 


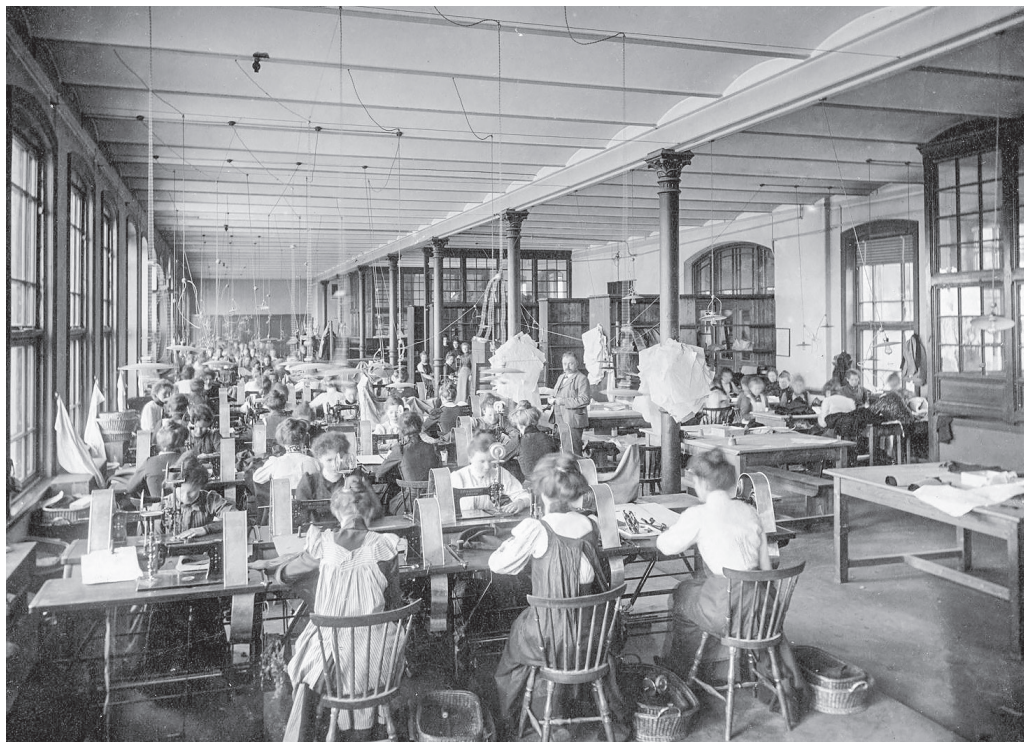

Bild 8.2. Sömmerskor på inne i fabriksbyggnaden på Wettergrens kappfabrik på Masthugget 1901. Foto: okänd, Göteborgs stadsmuseum.

än de gifta. Ogifta kvinnor hade även oftare genomgått yrkesutbildning som Anna Josefina i exemplet ovan; oftast hade de arbetat som syflickor i verkstäder eller gått en utbildning hos Wettergrens eller någon annan större arbetsgivare.

En yrkesgrupp som i snitt arbetat länge i hemindustrin var brodöserna. Många var äldre och ogifta, och de hade till viss del en annan klassbakgrund än till exempel linnesömmerskorna. Linnesömmerskorna hade utpräglad arbetarklassbakgrund, men brodöserna kunde ha en borgerlig bakgrund. Emilia Ekström var vid intervjutillfället 54 år och hade arbetat som brodös i 30 år. Hon broderade varje dag, elva månader om året, även söndagar. Hon kunde dock inte uppge hur många timmar om dagen hon broderade. Jag hittade henne i mantalslängden alla år fram till 1932, alltid som "släkting" eller "fröken".

I tabell 8.4 sammanfattas hemsömmerskornas arbetstid och inkomster. I snitt arbetade de omkring nio timmar per dag, exklusive pauser, fem dagar i veckan. Gifta kvinnor arbetade något kortare dagar än ogifta, och de få änkorna i urvalet arbetade längre dagar. Inkomsten 
Tabell 8.2. Yrke, antal anställda och innehav av verkstad, Göteborg 1912. Anm: *Övrigt = tvätt och strykning, pressning, "olika varor", mönsterriterska, märkning, nåtling av skor, måla tennsoldater, göra flaggor. Källa: Socialstyrelsens arkiv, 4:e byrån. Svensk hemindustri.

\begin{tabular}{|c|c|c|c|c|c|c|c|}
\hline & \multicolumn{2}{|c|}{ Gifta } & \multicolumn{2}{|c|}{ Ogifta } & \multirow{2}{*}{$\begin{array}{c}\text { Änkor } \\
\mathrm{N}\end{array}$} & \multicolumn{2}{|c|}{ Totalt } \\
\hline & $\mathrm{N}$ & $\%$ & $\mathbf{N}$ & $\%$ & & $\mathrm{~N}$ & $\%$ \\
\hline \multicolumn{8}{|l|}{ Yrke } \\
\hline Brodös & 6 & 10 & 16 & 23 & 1 & 23 & 17 \\
\hline Trikåstickerska & 5 & 8 & 5 & 7 & 0 & 10 & 7 \\
\hline Övrigt* & 2 & 3 & 6 & 8 & 1 & 9 & 7 \\
\hline Klädsömmerska & 5 & 8 & 3 & 4 & 2 & 10 & 7 \\
\hline Kappsömmerska & 11 & 19 & 26 & 37 & 1 & 38 & 28 \\
\hline Linnesömmerska & 30 & 51 & 15 & 21 & 2 & 47 & 34 \\
\hline \multicolumn{8}{|l|}{ Anställda } \\
\hline 0 & 47 & 80 & 45 & 63 & 5 & 97 & 71 \\
\hline $1-3$ & 8 & 14 & 9 & 13 & 1 & 18 & 13 \\
\hline $4-6$ & 3 & 5 & 13 & 18 & 1 & 17 & 12 \\
\hline $7+$ & 1 & 2 & 4 & 6 & 0 & 5 & 4 \\
\hline \multicolumn{8}{|l|}{ Verkstad } \\
\hline $\mathrm{Ja}$ & 3 & 5 & 13 & 18 & 1 & 17 & 12 \\
\hline Nej & 55 & 93 & 56 & 79 & 6 & 117 & 85 \\
\hline
\end{tabular}

Tabell 8.3. Arbetade år i hemindustrin och yrkesträning, efter civilstånd, Göteborg 1912. Källa: Socialstyrelsens arkiv, 4:e byrån. Svensk hemindustri.

\begin{tabular}{lccccc} 
Civilstånd & Min & Median & Medel & Max & Standardavvikelse \\
\hline \multicolumn{2}{l}{ Arbetade år i hemindustrin } & & & & \\
Gifta & 0,5 & 3 & 7 & 40 & 9 \\
Ogifta & 1 & 7 & 9 & 30 & 8 \\
Änkor & 0,5 & 10 & 10 & 23 & 8 \\
\hline
\end{tabular}

\begin{tabular}{lrrrr} 
Civilstånd & \multicolumn{2}{c}{ Har yrkesträning } & \multicolumn{2}{c}{ Har ej yrkesträning } \\
& N & $\%$ & N & $\%$ \\
\hline Yrkesträning & & & & \\
Gifta & 7 & 12 & 52 & 88 \\
Ogifta & 20 & 28 & 51 & 72 \\
Änkor & 1 & 14 & 6 & 86 \\
Totalt & 28 & 20 & 109 & 80 \\
\hline
\end{tabular}


Tabell 8.4. Arbetstid och inkomst hos hemindustriarbeterskorna i kohorten, Göteborg 1912. Källa: Socialstyrelsens arkiv, 4:e byrån. Svensk hemindustri.

\begin{tabular}{lccccc} 
Civilstånd & Min & Median & Medel & Max & Standardavvikelse \\
\hline Timmar arbetade perdag & 1 & 7 & 7 & 13 & 3 \\
Gifta & 1 & 9 & 9 & 15 & 3 \\
Ogifta & 7 & 8 & 10 & 16 & 4 \\
Änkor & 1 & 5 & 6 & 15 & 3 \\
\hline Inkomst per vecka i kronor & 4 & 8 & 10 & 25 & 5 \\
Gifta & 3 & 5 & 7 & 14 & 6 \\
Ogifta & & & & & \\
Änkor & & &
\end{tabular}

per vecka varierade också med civilståndet; gifta tjänade mindre än ogifta och änkor i snitt. Hemsömmerskorna jobbade uteslutande på ackord, de fick betalt per färdig produkt och inte per timme.

\section{Vad gjorde de innan de blev hemsömmerskor?}

Vad hade kvinnorna gjort innan de började arbeta som hemsömmerskor? Ungefär hälften av dem uppgav i intervjun att de inte haft något annat yrke. Ungefär en tredjedel hade arbetat som sömmerskor, exempelvis, som i textrutan på sida 209, på en fabrik eller i en annan sömmerskas verkstad. Flera hade arbetat som sömmerskor på Wettergrens innan de blev hemsömmerskor och fortsatte att sy för fabriken i sitt eget hem eller sin egen verkstad.

Vissa av kvinnorna hade aldrig arbetat i en fabrik utan gick från att arbeta på en annan sömmerskas verkstad till att öppna en egen. Hanna Rydberg hade till exempel arbetat på verkstad i 14 år innan hon blev hemsömmerska. Det innebar att hon börjat där som tolvåring, och nu 34 år senare hade hon en egen verkstad med nio anställda. Andra angav att de hade "sytt privat", det vill direkt för konsumenter, innan de blev hemsömmerska.

Dessa kvinnors övergång till hemindustrin hade representerat någon yrkesmobilitet. De utövade samma yrke, men på en annan plats eller för en annan arbetsgivare. 


\section{Vittnesmål om hur hemmafrun också kunde vara hemsömmerska}

Greta, född 1914, berättar om hur hennes mamma, som tidigare varit sömmerska i en väskfabrik på Lindholmen, blev hemsömmerska.

Det var fattigt i vår familj, mamma blev hemsömmerska när pappa slutade som rörläggare. Hon sa till honom "Sluta, jag kan börja sy". Han hade tur som så snart fick jobb på SJ:s verkstad 1920. Mamma sydde kläder, damkläder, kappor och klänningar. Hon satt uppe mycket på nätterna och sydde för att få ihop lite pengar. Ofta hade de som skulle betala för kläderna inte råd när de skulle hämta dem, vi sydde för folk i stadsdelen. De kanske bara kunde betala en liten del av vad det kostade. Mamma brukade ge dem kläderna ändå, men det var många som aldrig betalade resten. En del kom med några ören då och då. (Sjöstedt 2008, s 13)

Längre fram i berättelsen konstaterar Greta:

Min mamma jobbade med att sy, men hon räknades ändå som hemmafru. (Sjöstedt 2008, s 16)

Beträffande kappsömmerskorna skulle man dock kunna hävda att många av dem upplevde någon form av vertikal social mobilitet eftersom de fick högre inkomst och status när de övergick från att sy på fabrik till att sy i sin egen verkstad. Flera av dem som hade verkstad hade också anställda och verkar ha haft en arbetsledande roll. De kunde tjäna en hel del pengar, i alla fall om man jämför med linnesömmerskorna som arbetade ensamma i sitt eget hem.

Linnesömmerskor kunde också uppleva horisontell mobilitet i meningen att de bytte arbetsplats från fabriken till hemmet men fortsatte med ungefär samma typ av uppgifter. En av respondenterna, Mathilda Almgren, hade arbetat på Korsettfabriken fram tills strax innan hon fick en son drygt ett år före intervjutillfället. Mathilda var en ogift mor och arbetade nio till tio timmar per dag med att sy enkla linneprodukter för firman Yngve Östberg. Hon arbetade i det spisrum som hon delade med sin son, sin mor och två yngre syskon. Modern hade enligt vad Mathilda uppgav i intervjun tjänat 50 kronor under föregående år, i övrigt var hela familjen beroende av hennes inkomster. 
Mathildas arbetsgivare försökte dock motivera hemarbetarnas låga löner med att kvinnorna inte var primära familjeförsörjare. I ett brev till Socialstyrelsen lät han meddela:

Till uppgift för hemarbetesutredningen får jag meddela att jag har 160 hemsömmerskor [...]. Dock är dessa yngre gifta kvinnor (spårvägsfruar) som ej uteslutande lefva utav denna förtjänst. ${ }^{29}$

Av linnesömmerskorna verkar vissa ha upplevt en vertikal mobilitet nedåt: på Wettergrens hade de sytt avancerade kappor, men i sitt eget hem började de sy enkla daglinnen. Ofta verkar detta ha hört samman med deras civilstånd: kompetenta ogifta kvinnor som arbetade på Wettergrens fabrik kunde bli utesömmerskor och driva en egen verkstad, men sömmerskor som arbetade inne på fabriken och gifte sig började oftare sy enklare plagg, och då för en annan arbetsgivare. Johanna Andersson hade arbetat som kappsömmerska men arbetade vid intervjutillfället sedan tre år tillbaka med att sy linnen. Hon bodde med sin man, sin svåger och sin två år gamle son. Det finns en anteckning om att hon förutom linnesömnaden också "syr privat".

Förklaringen ligger antagligen i behovet av omsorgsarbete och investeringar. Linnesömmerskorna kunde komma upp i ett hyfsat ackord genom att sy daglinnen på en egen enklare maskin eller för hand. Arbetet kunde pausas för att ta hand om barn och hushåll. Men om du ska kunna sy avancerade kappor och tjäna pengar på det behöver du kunna investera i bättre maskiner, eventuellt en press, och gärna några anställda för att kunna dela upp arbetet. Det är svårare och dyrare att pausa ett sådant arbete för att ta hand om hushållet. Maskinerna kostar pengar, och alternativkostnaden för att inte arbeta är större.

Knappt en femtedel av kvinnorna hade haft ett annat yrke innan de blev hemsömmerskor, det vill säga att de hade upplevt yrkesmobilitet. Bland dem fanns en rad olika yrken representerade, som vi kan se i tabell 8.5. Det vanligaste var att ha varit tjänsteflicka eller butiksbiträde. Men som vi såg i vårt inledande exempel med Anna Josefina är det oklart hur många som faktiskt rapporterade sina tidigare yrken, särskilt om de hade utfört husligt arbete eller till exempel arbetat på sina föräldrars gård innan de migrerade till Göteborg. 
Tabell 8.5. Yrken kvinnorna haft före arbetet i hemindustrin, Göteborg 1912. Anm: Procentandelarna summerar inte alltid till 100 på grund av avrundning till heltal. Källa: Socialstyrelsens arkiv, 4:e byrån. Svensk hemindustri.

\begin{tabular}{|c|c|c|c|c|c|c|c|}
\hline \multirow[t]{2}{*}{ Tidigare yrke } & \multicolumn{2}{|c|}{ Gifta } & \multicolumn{2}{|c|}{ Ogifta } & \multirow{2}{*}{$\begin{array}{c}\text { Änkor } \\
\mathrm{N}\end{array}$} & \multicolumn{2}{|c|}{ Totalt } \\
\hline & $\mathrm{N}$ & $\%$ & $\mathrm{~N}$ & $\%$ & & $\mathrm{~N}$ & $\%$ \\
\hline Ingen tidigare yrkeserfarenhet & 27 & 46 & 37 & 52 & 3 & 67 & 49 \\
\hline \multicolumn{8}{|c|}{ Yrken som de fortsatte med i hemmet } \\
\hline Sömmerska & 16 & 27 & 20 & 28 & 2 & 38 & 28 \\
\hline Riterska & & & 1 & 1 & & 1 & 1 \\
\hline Brodös & 1 & 2 & 2 & 3 & & 3 & 2 \\
\hline Summa & 17 & 29 & 23 & 32 & 2 & 42 & 31 \\
\hline \multicolumn{8}{|c|}{ Yrken som de ej fortsatte med i hemmet } \\
\hline Bagerska & 2 & 3 & & & & 2 & 1 \\
\hline Kartongmakerska & 1 & 2 & & & & 1 & 1 \\
\hline Städerska & 1 & 2 & & & & 1 & 1 \\
\hline Biträde & & & 1 & 1 & & 1 & 1 \\
\hline Försäljare & & & 1 & 1 & & 1 & 1 \\
\hline Fabriksarbeterska & 1 & 2 & & & & 1 & 1 \\
\hline Förgyllare & 1 & 2 & & & & 1 & 1 \\
\hline Hushållerska & & & 1 & 1 & & 1 & 1 \\
\hline Piga & & & & & 1 & 1 & 1 \\
\hline Musiklärarinna & & & 1 & 1 & & 1 & 1 \\
\hline Barnsköterska & & & 1 & 1 & & 1 & 1 \\
\hline Presserska & 1 & 2 & & & & 1 & 1 \\
\hline Tjänsteflicka & 5 & 8 & & & 1 & 6 & 4 \\
\hline Butiksbiträde & 3 & 5 & 2 & 3 & & 5 & 4 \\
\hline Lärarinna & & & 3 & 4 & & 3 & 2 \\
\hline Uppgift saknas & & & 1 & 1 & & 1 & 1 \\
\hline Summa & 15 & 26 & 11 & 13 & 2 & 28 & 23 \\
\hline Totalt & 59 & 101 & 71 & 98 & 7 & 137 & 103 \\
\hline
\end{tabular}

De flesta som bytte från ett annat yrke bytte till linnesömnad eller broderi, alltså relativt okvalificerad sömnad. Av de gifta kvinnorna bytte många till linnesömnad. Som Johanna Hellström; hon angav att hon "innan giftermålet" hade arbetat som affärsbiträde. $\mathrm{Nu}$ sydde hon daglinnen cirka sex timmar varje dag under säsong, 
Tabell 8.6. Titel i mantalslängd, efter civilstånd, Göteborg 1912. Anm: Procentandelarna summerar inte alltid till 100 på grund av avrundning till heltal. Källa: Göteborgs mantalskontors arkiv, mantalslängder 1912.

\begin{tabular}{lrrrrrrr} 
Titel i mantalslängd & \multicolumn{2}{c}{ Gifta } & \multicolumn{2}{c}{ Ogifta } & \multicolumn{2}{c}{ Änkor } & \multicolumn{2}{c}{ Totalt } \\
& N & $\%$ & N & $\%$ & N & N & $\%$ \\
\hline Yrkestitel & 1 & 2 & 49 & 63 & 1 & 51 & 36 \\
Familjetitel (t ex dotter, hustru) & 37 & 67 & 16 & 21 & 6 & 59 & 42 \\
Ingen titel & 17 & 31 & 13 & 17 & 1 & 31 & 22 \\
\hline Totalt & $\mathbf{5 5}$ & $\mathbf{1 0 0}$ & $\mathbf{7 8}$ & 101 & $\mathbf{8}$ & 141 & 100 \\
\hline
\end{tabular}

Tabell 8.7. Yrkesbanor efter civilstånd, Göteborg 1912-1943. Anm: Procentandelarna summerar inte alltid till 100 på grund av avrundning till heltal. Källa: Göteborgs mantalskontors arkiv, mantalslängder 1912, 1916, 1920, 1924, 1928, 1932, 1936, 1940, 1944.

\begin{tabular}{lrrrrr} 
Yrkesbana & \multicolumn{2}{c}{ Gifta } & \multicolumn{2}{c}{ Ogifta } & Änkor \\
& N & $\%$ & N & $\%$ & N \\
\hline 1. Registrerar aldrig yrke & 37 & 73 & 11 & 17 & 5 \\
2. Registrerar samma yrke hela perioden & 1 & 2 & 35 & 55 & 1 \\
3. Byter till eller från titeln "hustru" & 7 & 14 & 5 & 8 & 0 \\
4. Byter till annan yrkestitel & 6 & 12 & 13 & 20 & 1 \\
\hline Totalt & $\mathbf{5 1}$ & 100 & 64 & 100 & 7 \\
\hline Förekommer mindre än tre gånger & 8 & 14 & 7 & 10 & 0 \\
i mantalslängden & & & & & \\
\hline
\end{tabular}

cirka nio månader om året. I hushållet fanns förutom Johannas man, som arbetade som chaufför, och deras två barn, som var tre och ett år gamla, även mannens mor.

\section{Hur syns de gifta hemsömmerskornas arbete i mantalslängden?}

Från intervjuerna vet jag att alla hemsömmerskor som intervjuades inom ramen för hemindustriutredningen i Göteborg förvärvsarbetade, i snitt sju till nio timmar per dag, ogifta som gifta. Men i mantalslängden samma år, 1912, är det bara en av 55 gifta kvinnor som uppges ha ett yrke. Av de ogifta är det däremot en majoritet, 49 av 78 (tabell 8.6). 
Diagram 8.2. Andel kvinnor som registrerade yrke, efter civilstånd, Göteborg 1911-1943 (procent). Källa: Göteborgs mantalskontors arkiv, mantalslängder 1912, 1916, 1920, 1924, 1928, 1932, 1936, 1940, 1944.

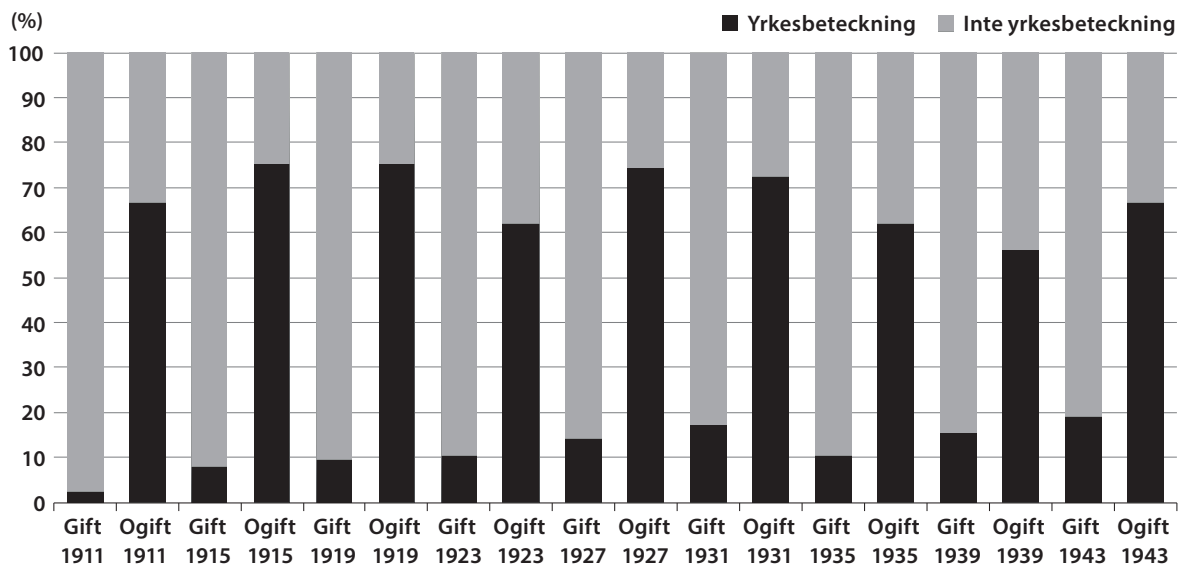

I diagram 8.2 ser vi att samma förhållande består under hela undersökningsperioden, även om grupperna närmar sig varandra. Det avspeglar dock sannolikt inte en allmän trend att fler gifta och färre ogifta kvinnor registrerade yrken utan snarare gruppens sammansättning och åldrande.

I tabell 8.7 ser vi samma tendens: gifta kvinnor registrerade i de flesta fall aldrig ett yrke. Bland de ogifta ser vi att de flesta registrerade samma yrke; de stod som sömmerska varje gång jag fann dem i mantalslängden.

\section{Slutsatser}

Tre huvudsakliga slutsatser dras av detta kapitel. För det första att mantalslängder är ofullständiga källor för gifta kvinnors förvärvsarbete i början av 1900-talet, vilket bekräftar tidigare forskning. Det var särskilt uppenbart 1912, när jag visste att alla de gifta kvinnorna i mitt material arbetade inom hemindustrin, men i princip ingen av dem registrerade ett yrke. Att de inte gjorde det kan ha berott på att en manlig försörjarnorm växte fram i samhället om att gifta kvin- 
nor inte skulle eller förväntades arbeta och att det vore förknippat med en statusförlust för mannen. Det kan också ha berott på att kvinnorna hade få incitament att faktiskt registrera sitt yrke. Gränsen för beskattning var relativt hög, 1912 var den 800 kronor, och få hemsömmerskor tjänade mer än så.

Min andra slutsats är att den yrkesmobilitet som kvinnorna uppvisade i samband med att de gifte sig ofta gick i riktning mot mindre kvalificerade arbeten. De kan till exempel ha varit kvalificerade kappsömmerskor på Wettergrens och sedan i hemindustrin ha ägnat sig åt enklare linnesömnad. För ogifta kvinnor var det vanligare att deras intåg i hemindustrin innebar att de fick större ansvar för och inflytande över produktionsprocessen och i vissa fall till och med kunde anställa andra kvinnor.

Nästan tre fjärdedelar av de gifta hemsömmerskorna registrerade aldrig något yrke. Endast en av dem angav konsekvent sitt yrke i mantalslängden; hon står som sömmerska. Beträffande de gifta kvinnor som bytte från eller till titeln "hustru" (14 procent) är det möjligt att det speglar hur de gick in i och ut ur arbetskraften. Endast 12 procent av de gifta kvinnorna registrerade en yrkestitel någon gång under perioden.

Min tredje slutsats är att förvånansvärt många kvinnor arbetade som hemsömmerskor under större delen av, eller hela, sitt yrkesliv. Av de hemsömmerskor som var ogifta 1912 registrerade över hälften samma yrke hela perioden, nästan alltid "sömmerska". En handfull gifte sig och lämnade eventuellt arbetsmarknaden - de slutade i varje fall uppge titeln "sömmerska" och uppgav istället "hustru". En femtedel av de ogifta bytte till ett annat yrke någon gång efter 1912: till bagare, butiksbiträde, städerska, fabriksarbeterska, hushållerska, lärarinna eller trikåstickerska.

Av de hemsömmerskor jag kunde följa stannade de flesta kvar i sitt yrke. Det talar mot tidigare forskning, som sett hemindustriarbete primärt som ett sätt för gifta kvinnor att under en kort period komplettera sin makes inkomst. Anna Josefina, vars livsberättelse jag återgav, stannade kvar i yrket, och även de ogifta kvinnor som jag hittade i mantalslängderna fortsatte att ange "sömmerska" som 
sitt yrke. De kunde dock utöva yrket inom olika typer av arbetsmarknadsrelationer - de har till exempel börjat som syflickor på en verkstad, sedan jobbat några år som sömmerskor på fabrik, sedan gift sig och sytt enklare plagg hemma eller som föreståndare på en egen verkstad. Antagligen sydde dessa kvinnor även familjens kläder och vissa arbetade parallellt med att utföra sömmersketjänster åt privatpersoner. Så även om dessa kvinnor bara under en kort tid officiellt befann sig på arbetsmarknaden, på en formell arbetsplats, kunde de under lång tid använda sig av sina färdigheter som sömmerskor. Det är intressant också ur perspektivet att många teorier om varför kvinnor hamnar efter män på arbetsmarknaden handlar om att de har mindre incitament att investera i sina yrken eftersom de är på arbetsmarknaden under en mycket kortare period.

\section{Noter}

1 Vikström 2011.

2 Lane 2004.

3 Frangeur 1998.

4 Horrell \& Humphries 1995; Knotter 2004.

5 Fraundorf 1979; Goldin 1983; Nilsson 2020.

6 Svensk Hemindustri. Del 11917.

7 Schulz, Maas \& van Leeuwen 2014.

8 Holmberg 2013; Schulz 2013; kapitel 4 och 7 i denna antologi.

9 Meidner 1954. I samma riktning pekar resultaten i kapitel 4, som visar att andelen personer som upplevde arbetskraftsmobilitet sammantaget var högre bland kvinnor än män.

10 Lundh 1999a,b.

11 Ling et al 2017.

12 Uppenberg 2018, s 185.

13 Lundh 1999a,b.

14 Goldin 1994.

15 Schmidt \& van Nederveen Meerkerk 2012, s 630; Humphries \& Sarasúa 2012.

16 Silenstam 1970.

17 Nyberg 1987.

18 Fritz 1996, s 198.

19 Klintberg \& Nyberg 2019, s 138.

20 Meyerson 1907.

21 Karlsson 1995, s 27; Carlsson Wetterberg 1986, s 44; Frangeur s 49; Åmark 2005, s 73-74.

22 Stanfors 2007, s 84 . 
23 Tilly \& Scott 1987, s 124.

24 Tilly, Tilly \& Scott, s 125.

25 Burnette 2008.

26 Elson 1999; Chant 2011, s 474.

27 Se appendix.

28 Se appendix.

29 Yngve Östberg, "Brev Från Yngve Östberg till Hemindustriutredningen", 10 juni 1912, Socialstyrelsens 5:e byrå, H2BD Svensk Hemindustri. 